\title{
Design and Characterization of Effervescent Gastro Retentive Floating Tablets by Using Venlafaxine Hcl as a Model Drug
}

\author{
Asfia Kauser *, Ayesha Haseena, Faheem Unnisa Begum, Taiyaba Fatima \\ *Assistant Professor, Shadan Women's College of Pharmacy, Khiartabad, Hyderabad Department of \\ Pharmaceutics
}

\begin{abstract}
In the present research work the gastro retentive floating matrix formulation of Venlaflaxine hydrochloride by using various hydrophillic polymers. Initially analytical method development was done for the drug molecule. Absorption maxima was determined based on that calibration curve was developed by using different concentrations. Gas generating agent sodium bicarbonate concentration was optimized. Then the formulation was developed by using different concentrations of polymers of various grades of HPMC and Guar gum. The formulation blend was subjected to various preformualation studies, flow properties and all the formulations were found to be good indicating that the powder blend has good flow properties. Among all the formulations the formulations prepared by using Guar gum were in the concentration of $120 \mathrm{mg}$ (F4) showed maximum drug release $99.76 \%$ in 12 hours with good floating lag time and duration of floating. The formulations prepared with HPMC K $15 \mathrm{M}$ retarded the drug release up to 12 hours in the concentration of 120 $m g$ (F8).The formulations prepared with HPMC K100M were also retarded the drug release for more than 12 hours. Hence they were not considered. The optimized formulation dissolution data was subjected to release kinetics; from the release kinetics data it was evident that the formulation followed peppas mechanism of drug release.
\end{abstract}

Keywords: Venlaflaxine hydrochloride, HPMC polymers, Floating tablets.

\section{Introduction}

Oral drug delivery is the most widely utilized route of administration among all the routes that have been explored for systemic delivery of drugs via pharmaceutical products of different dosage form. Oral route is considered most natural, uncomplicated, convenient and safe due to its ease of administration, patient acceptance and cost-effective manufacturing process.

In order to overcome the drawbacks of conventional drug deliver systems, several technical advancements have led to the development of controlled drug delivery system that could revolutionize method of medication and provide a number of therapeutic benefits .

\subsection{Gastro Retentive Dosage Form (Grdf)}

It is evident from the recent scientific and patient literature that an increased interest in novel dosage forms that are retained in stomach for a prolonged and predictable period of time exists today in academic and industrial research groups. One of the most feasible approaches for achieving a prolonged and predictable drug delivery in the GI tract is to control the gastric residence time (GRT), i.e. gastro retentive dosage form (GRDFs or GRDS).

GRDFs extend significantly the period of time over which the drugs may be released. They not only prolong dosing intervals, but also increase patient compliance beyond the level of existing controlled release dosage form.

Dosage form with prolonged GRT, i.e. gastro retentive dosage form (GRDF), will bring about new and important therapeutic options such as -

1) This application is especially effective in sparingly soluble and insoluble drugs. It is known that, as the solubility of a drug decreases, the time available for drug dissolution becomes less adequate and thus the transit time becomes a significant factor affecting drug absorption. To override this problem, erodible, gastro retentive dosage forms have been developed that provide continuous, controlled administration of sparingly soluble drugs at the absorption site.

2) GRDFs greatly improve the pharmacotherapy of the stomach through local drug release, leading to high drug concentration at the gastric mucosa. (For e.g. Eradicating Helicobacter pylori from the sub mucosal tissue of stomach) making it possible to treat stomach and duodenal ulcers, gastritis and oesophagitis, reduce the risk of gastric carcinoma and administer non-systemic controlled release antacid formulations (calcium carbonate). 


\subsection{Approaches To Gastric Retention}

Various approaches have been pursued to increase the retention of an oral dosage form in the stomach. These systems include: Floating systems, Bio adhesive systems, swelling and expanding systems, High density systems, Modified systems

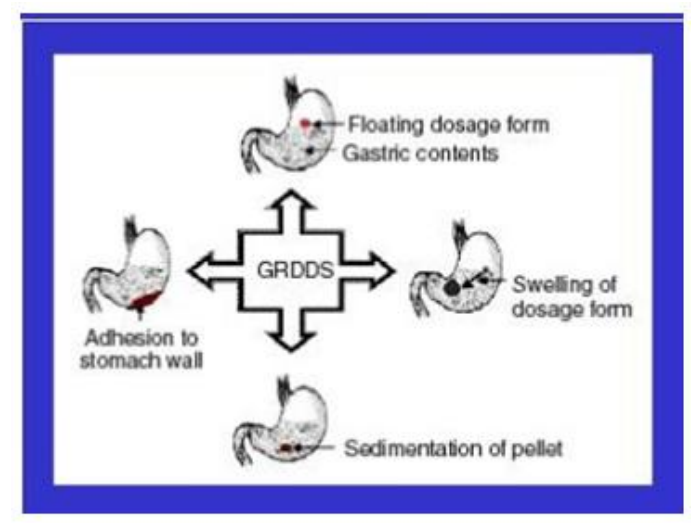

Fig: Classification of gastro retentive drug delivery system

1 Buoyant/ Floating Systems

2 Bio/Muco-adhesive Systems

3 Swelling and Expanding Systems

4 High Density Systems

5 Incorporation of Passage Delaying Food Agents

6 Ion Exchange Resins

7 Osmotic Regulated Systems

\subsection{TYPES OF FLOATING DRUG DELIVERY SYSTEMS (FDDS)}

Based on the mechanism of buoyancy, two distinctly different technologies have been utilized in development of FDDS which are:

A. Effervescent System, and

B. Non- Effervescent System.

\subsubsection{EFFERVESCENT SYSTEM}

Effervescent systems include use of gas generating agents, carbonates (ex. Sodium bicarbonate) and other organic acid (e.g. citric acid and tartaric acid) present in the formulation to produce carbon dioxide $\left(\mathrm{CO}_{2}\right)$ gas, thus reducing the density of the system and making it float on the gastric fluid. An alternative is the incorporation of matrix containing portion of liquid, which produce gas that evaporates at body temperature.

These effervescent systems further classified into two types.

I. Gas Generating systems

II. Volatile Liquid/Vacuum Containing Systems.

\subsubsection{NON-EFFERVESCENT SYSTEMS}

The Non-effervescent FDDS based on mechanism of swelling of polymer or bioadhesion to mucosal layer in GI tract. The most commonly used excipients in non-effervescent FDDS are gel forming or highly swellable cellulose type hydrocolloids, polysaccharides and matrix forming material such as Polycarbonate, Polyacrylate, Polymethacrylate, polystyrene as well as bioadhesive polymer such as Chitosan and Carbopol. The various types of this system are as:

1 Single Layer Floating Tablets

2 Bilayer Floating Tablets

3 Alginate Beads

\section{ADVANTAGES OF FDDS}

Floating dosage systems form important technological drug delivery systems with gastric retentive behavior and offer several advantages in drug delivery. These advantages include:

1. Improved drug absorption, because of increased GRT and more time spent by the dosage form at its absorption site.

2. Controlled delivery of drugs.

3. Delivery of drugs for local action in the stomach. 


\section{DISADVANTAGES OF FDDS}

1. Gastric retention is influenced by many factors such as gastric motility, $\mathrm{pH}$ and presence of food. These factors are never constant and hence the buoyancy cannot be predicted.

2. Drugs that cause irritation and lesion to gastric mucosa are not suitable to be formulated as floating drug delivery systems.

3. High variability in gastric emptying time due to its all or non-emptying process.

\section{Materials}

\begin{tabular}{|l|}
\hline Name of the material \\
\hline Venlafaxine hydrochloride \\
\hline Hydroxy Propyl Methyl Cellulose grades \\
\hline Guar gum \\
\hline Sodium bicarbonate \\
\hline Magnesium stearate \\
\hline Micro crystalline cellulose \\
\hline Talc \\
\hline
\end{tabular}

\subsection{ANALYTICAL METHOD DEVELOPMENT}

\section{Methodology}

\section{DETERMINATION OF ABSORPTION MAXIMA}

A solution containing the concentration $10 \mu \mathrm{g} / \mathrm{ml}$ drug was prepared in $0.1 \mathrm{~N} \mathrm{HCl} \mathrm{UV} \mathrm{spectrum} \mathrm{was} \mathrm{taken} \mathrm{using}$ Double beam UV/VIS spectrophotometer. The solution was scanned in the range of $200-400$.

\section{PREPARATION CALIBRATION CURVE}

$100 \mathrm{mg}$ of Venlaflaxine $\mathrm{HCl}$ pure drug was dissolved in $100 \mathrm{ml}$ of water(stock solution) $10 \mathrm{ml}$ of solution was taken and make up with $100 \mathrm{ml}$ of water $(100 \mu \mathrm{g} / \mathrm{ml})$.from this $10 \mathrm{ml}$ was taken and make up with $100 \mathrm{ml}$ of water $(10 \mu \mathrm{g} / \mathrm{ml})$. The above solution was subsequently diluted with $0.1 \mathrm{~N} \mathrm{HCl}$ to obtain series of dilutions Containing 5, 10, 15, 20 and $25 \mu \mathrm{g} / \mathrm{ml}$ of Venlaflaxine $\mathrm{HCl}$ per $\mathrm{ml}$ of solution. The absorbance of the above dilutions was measured at $225 \mathrm{~nm}$ by using UV-Spectrophotometer taking $0.1 \mathrm{~N} \mathrm{HCl}$ as blank. Then a graph was plotted by taking Concentration on X-Axis and Absorbance on Y-Axis which gives a straight line Linearity of standard curve was assessed from the square of correlation coefficient $\left(\mathrm{R}^{2}\right)$ which determined by least-square linear regression analysis.

\subsection{DRUG - EXCIPIENT COMPATIBILITY STUDIES FOURIER TRANSFORMS INFRARED (FTIR) SPECTROSCOPY}

The physical properties of the physical mixture were compared with those of plain drug. Samples was mixed thoroughly with $100 \mathrm{mg}$ potassium bromide IR powder and compacted under vacuum at a pressure of about 12 psi for 3 minutes. The resultant disc was mounted in a suitable holder in Perkin Elmer IR spectrophotometer and the IR spectrum was recorded from $3500 \mathrm{~cm}$ to $500 \mathrm{~cm}$. The resultant spectrum was compared for any spectrum changes.

\subsection{PREFORMULATION PARAMETERS}

The quality of tablet, once formulated by rule, is generally dictated by the quality of physicochemical properties of blends. There are many formulations and process variables involved in mixing and all these can affect the characteristics of blends produced. The various characteristics of blends tested as per Pharmacopoeia.

\section{ANGLE OF REPOSE}

The frictional force in a loose powder can be measured by the angle of repose. It is defined as, the maximum angle possible between the surface of the pile of the powder and the horizontal plane. The angle of repose was calculated using the following formula;

Tan $\theta=\mathrm{h} / \mathrm{r}$

Tan $\theta=$ Angle of repose, $\mathrm{h}=$ Height of the cone, $\mathrm{r}=$ Radius of the cone base

\section{BULK DENSITY}

Density is defined as weight per unit volume. Bulk density, is defined as the mass of the powder divided by the bulk volume and is expressed as $\mathrm{gm} / \mathrm{cm}^{3}$.

The bulk density was calculated using the formula;

$$
\text { Bulk Density }=\mathrm{M} / \mathrm{V}_{\mathrm{o}}
$$

Where, $\mathrm{M}=$ weight of sample, $\quad \mathrm{V}_{\mathrm{o}}=$ apparent volume of powder 


\section{TAPPED DENSITY}

The tapped density was calculated, in gm per L, using the formula;

$$
\text { Tap }=\mathrm{M} / \mathrm{V}
$$

Where, Tap= Tapped Density, $\quad M=$ Weight of sample, $\quad \mathrm{V}=$ Tapped volume of powder

\section{MEASURES OF POWDER COMPRESSIBILTY}

The Compressibility Index (Carr's Index) is a measure of the propensity of a powder to be compressed. It is determined from the bulk and tapped densities

Compressibility Index was calculated using the following formulas;

Carr's Index $=[($ tap - b) $/$ tap $] \times 100$

Where, $\mathrm{b}=$ Bulk Density, Tap = Tapped Density

\section{HAUSNER RATIO}

Hausner ratio is an indirect index of ease of powder flow. It is calculated by the following formula;

$$
\text { Hausner's Ratio=Tapped density / Bulk density }
$$

\subsection{FORMULATION DEVELOPMENT OF TABLETS}

All the formulations were prepared by direct compression. The compression of different formulations are given in Table 6.3.The tablets were prepared as per the procedure given below and aim is to prolong the release of Venlaflaxine Hydrochloride. Total weight of the tablet was considered as $300 \mathrm{mg}$.

\section{PROCEDURE}

1) Venlaflaxine $\mathrm{HCl}$ and all other ingredients were individually passed through sieve no $\neq 60$.

2) All the ingredients were mixed thoroughly by triturating up to $15 \mathrm{~min}$.

3) The powder mixture was lubricated with talc.

4) The tablets were prepared by using direct compression method.

\section{OPTIMIZATION OF SODIUM BICARBONATE CONCENTRATION}

Sodium bicarbonate was employed as effervescent gas generating agent. It helps the formulation to float. Various concentrations of sodium bicarbonate were employed; floating lag time and floating duration were observed. Based on the concentration of sodium bicarbonate was finalized and preceded for further formulations.

TABLE: Optimization sodium bicarbonate concentration

\begin{tabular}{|l|l|l|l|l|}
\hline S.No & Excipient Name & F1 & F2 & F3 \\
\hline 1 & Venlafaxine & 75 & 75 & 75 \\
\hline 2 & HPMC K 100M & 100 & 100 & 100 \\
\hline 3 & NaHCO $_{3}$ & 25 & 50 & 75 \\
\hline 4 & Mg.Stearate & 5 & 5 & 5 \\
\hline 5 & Talc & 5 & 5 & 5 \\
\hline 6 & MCC pH 102 & 90 & 65 & 40 \\
\hline
\end{tabular}

All the quantities were in $\mathrm{mg}$ Based on the floating lag time and floating duration the concentration of sodium bicarbonate was optimised.

\begin{tabular}{|c|c|c|c|c|c|c|c|c|}
\hline $\begin{array}{l}\text { FORMUAT } \\
\text { ION NO. }\end{array}$ & $\begin{array}{l}\text { VENLAFAX } \\
\text { INE HCL }\end{array}$ & GAUR GUM & HPMC K15 & HPMC K100 & NAHCO3 & $\begin{array}{l}\text { MAG. } \\
\text { STEARATE }\end{array}$ & TALC & МСC РН 102 \\
\hline F1 & 75 & 30 & & & 50 & 5 & 5 & 135 \\
\hline F2 & 75 & 60 & & & 50 & 5 & 5 & 105 \\
\hline F3 & 75 & 90 & & & 50 & 5 & 5 & 75 \\
\hline F4 & 75 & 120 & & & 50 & 5 & 5 & 45 \\
\hline F5 & 75 & & 30 & & 50 & 5 & 5 & 135 \\
\hline F6 & 75 & & 60 & & 50 & 5 & 5 & 105 \\
\hline F7 & 75 & & 90 & & 50 & 5 & 5 & 75 \\
\hline F8 & 75 & & 120 & & 50 & 5 & 5 & 45 \\
\hline F9 & 75 & & & 30 & 50 & 5 & 5 & 135 \\
\hline F10 & 75 & & & 60 & 50 & 5 & 5 & 105 \\
\hline F11 & 75 & & & 90 & 50 & 5 & 5 & 75 \\
\hline F12 & 75 & & & 120 & 50 & 5 & 5 & 45 \\
\hline
\end{tabular}

TABLE : Formulation Composition For Floating Tablets

All the quantities were in $\mathrm{mg}$, total weight is $300 \mathrm{mg}$. 


\subsection{EVALUATION OF POST COMPRESSION PARAMETERS FOR PREPARED TABLETS}

The designed formulation compression coated tablets were studied for their physicochemical properties like weight variation, hardness, thickness, friability and drug content.

\section{WEIGHT VARIATION TEST}

To study the weight variation, twenty tablets were taken and their weight was determined individually and collectively on a digital weighing balance. The average weight of one tablet was determined from the collective weight. The weight variation test would be a satisfactory method of deter mining the drug content uniformity. Not more than two of the individual weights deviate from the average weight by more than the percentage shown in the following table and none deviate by more than twice the percentage. The mean and deviation were determined. The percent deviation was calculated using the following formula.

$\%$ Deviation $=($ Individual weight - Average weight $/$ Average weight $) \times 100$

\section{HARDNESS}

Hardness of tablet is defined as the force applied across the diameter of the tablet in order to break the tablet. The resistance of the tablet to chipping, abrasion or breakage under condition of storage transformation and handling before usage depends on its hardness. For each formulation, the hardness of three tablets was determined using Monsanto hardness tester and the average is calculated and presented with deviation.

\section{THICKNESS}

Tablet thickness is an important characteristic in reproducing appearance. Tablet thickness is an important characteristic in reproducing appearance. Average thickness for core and coated tablets is calculated and presented with deviation.

\section{FRIABILITY}

It is measured of mechanical strength of tablets. Roche friabilator was used to determine the friability by following procedure. Preweighed tablets were placed in the friabilator. The tablets were rotated at $25 \mathrm{rpm}$ for 4 minutes (100 rotations). At the end of test, the tablets were re weighed, loss in the weight of tablet is the measure of friability and is expressed in percentage as

$\%$ Friability $=[(\mathrm{W} 1-\mathrm{W} 2) / \mathrm{W} 1] \times 100$

Where, $\mathrm{W} 1=$ Initial weight of three tablets

$\mathrm{W} 2=$ Weight of the three tablets after testing

\subsection{DETERMINATION OF DRUG CONTENTS}

Both compression-coated tablets of were tested for their drug content. Ten tablets were finely powdered quantities of the powder equivalent to one tablet weight of venlaflaxine were accurately weighed, transferred to a $100 \mathrm{ml}$ volumetric flask containing $50 \mathrm{ml}$ water and were allowed to stand to ensure complete solubility of the drug. The mixture was made up to volume with water. The solution was suitably diluted and the absorption was determined by UV -Visible spectrophotometer. The drug concentration was calculated from the calibration curve.

\subsection{IN VITRO BUOYANCY STUDIES}

The in vitro buoyancy was determined by floating lag time, and total floating time. (As per the method described by Rosa et al) The tablets were placed in a $100 \mathrm{ml}$ beaker containing $0.1 \mathrm{~N} \mathrm{HCl}$. The time required for the tablet to rise to the surface and float was determined as floating lag time (FLT) and duration of time the tablet constantly floats on the dissolution medium was noted as Total Floating Time respectively (TFT).

$\begin{array}{lcc}\text { INVITRO DRUG RELEASE STUDIES DISSOLUTION PARAMETERS: } \\ \text { Apparatus } & -- & \text { USP-II, Paddle Method } \\ \text { Dissolution Medium } & -- & 0.1 \mathrm{~N} \mathrm{HCl} \\ \text { RPM } & -- & 75 \\ \text { Sampling intervals (hrs) } & -- & \text { ss } 0.5,1,2,3,4,5,6,7,8,10,11,12 \\ \text { Temperature } & -- & 37^{\circ} \mathrm{c} \pm 0.5^{\circ} \mathrm{c}\end{array}$

As the preparation was for floating drug release given through oral route of administration, different receptors fluids are used for evaluation the dissolution profile.

\section{PROCEDURE}

900ml 0f $0.1 \mathrm{HCl}$ was placed in vessel and the USP apparatus -II (Paddle Method) was assembled. The medium was allowed to equilibrate to temp of $37^{\circ} \mathrm{c} \pm 0.5^{\circ} \mathrm{c}$. Tablet was placed in the vessel and the vessel was covered the apparatus was operated for 12 hours and then the medium $0.1 \mathrm{~N} \mathrm{HCl}$ was taken and process was

DOI: $10.9790 / 3008-1203020111 \quad$ www.iosrjournals.org $\quad 5 \mid$ Page


continued from 0 to $12 \mathrm{hrs}$ at $75 \mathrm{rpm}$. At definite time intervals of $5 \mathrm{ml}$ of the receptors fluid was withdrawn, filtered and again $5 \mathrm{ml}$ receptor fluid was replaced. Suitable dilutions were done with receptor fluid and analyzed by spectrophotometrically at $271 \mathrm{~nm}$ using UV-spectrophotometer.

\subsection{APPLICATION OF RELEASE RATE KINETICS TO DISSOLUTION DATA}

Various models were tested for explaining the kinetics of drug release. To analyze the mechanism of the drug release rate kinetics of the dosage form, the obtained data were fitted into zero-order, first order, Higuchi, and Korsmeyer-Peppas release model.

\section{ZERO ORDER RELEASE RATE KINETICS}

To study the zero-order release kinetics the release rate data are fitted to the following equation.

$\mathrm{F}=\mathrm{K}_{\mathrm{o}} \mathrm{t}$

Where, ' $F$ ' is the drug release at time ' $t$ ', and ' $\mathrm{K}_{\mathrm{o}}$ ' is the zero order release rate constant. The plot of $\%$ drug release versus time is linear.

\section{FIRST ORDER RELEASE RATE KINETICS}

The release rate data are fitted to the following equation $\log (100-\mathrm{F})=\mathrm{kt}$

A plot of log cumulative percent of drug remaining to be released vs. time is plotted then it gives first order release.

\section{HIGUCHI RELEASE MODEL}

To study the Higuchi release kinetics, the release rate data were fitted to the following equation.

$$
\mathrm{F}=\mathrm{kt} 1 / 2
$$

Where, ' $\mathrm{k}$ ' is the Higuchi constant.

In higuchi model, a plot of $\%$ drug release versus square root of time is linear.

\section{KORS MEYER AND PEPPAS RELEASE MODEL}

The mechanism of drug release was evaluated by plotting the log percentage of drug released versus log time according to Korsmeyer- Peppas equation. The exponent ' $n$ ' indicates the mechanism of drug release calculated through the slope of the straight Line.

$$
\mathrm{M}_{\mathrm{t}} / \mathrm{M}_{\infty}=\mathrm{K} \mathrm{t}^{\mathrm{n}}
$$

Where, $\mathrm{M}_{t} / \mathrm{M}_{\infty}$ is fraction of drug released at time ' $\mathrm{t}$ ', $\mathrm{k}$ represents a constant, and ' $\mathrm{n}$ ' is the diffusional exponent, which characterizes the type of release mechanism during the dissolution process. For non-Fickian release, the value of $\mathrm{n}$ falls between 0.5 and 1.0; while in case of Fickian diffusion, $\mathrm{n}=0.5$; for zero-order release (case I I transport), $\mathrm{n}=1$; and for supercase II transport, $\mathrm{n}>1$. In this model, a plot of $\log \left(\mathrm{M}_{\mathrm{t}} / \mathrm{M}_{\infty}\right)$ versus $\log ($ time) is linear.

\section{HIXSON-CROWELL RELEASE MODEL}

$\left(100-\mathrm{Q}_{\mathrm{t}}\right)^{1 / 3}=100^{1 / 3}-\mathrm{K}_{\mathrm{HC}} . \mathrm{t}$

Where, $\mathrm{k}$ is the Hixson-Crowell rate constant.

Hixson-Crowell model describes the release of drugs from an insoluble matrix through mainly erosion. (Where there is a change in surface area and diameter of particles or tablets).

\section{Results And Discussion}

The present study was aimed to developing gastro retentive floating tablets of Venlaflaxine hydrochloride using various HPMC polymers. All the formulations were evaluated for physicochemical properties and invitro drug release studies.

\subsection{ANALYTICAL METHOD}

Graphs of Venlaflaxine hydrochloride was taken in Simulated Gastric fluid (pH 1.2) at $225 \mathrm{~nm}$.

TABLE: Observations for graph of Venlaflaxine Hydrochloride in $0.1 \mathrm{~N} \mathrm{HCl}(225 \mathrm{~nm})$

\begin{tabular}{|l|l|}
\hline Conc $[\boldsymbol{\mu g} / \mathbf{l}]$ & Abs \\
\hline 5 & 0.163 \\
\hline 10 & 0.301 \\
\hline 15 & 0.441 \\
\hline 20 & 0.587 \\
\hline 25 & 0.73 \\
\hline
\end{tabular}




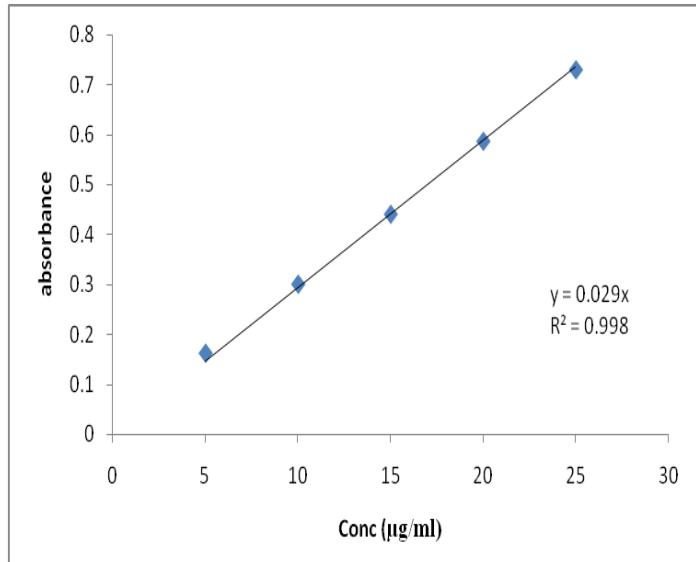

Fig: Standard graph of Venlafaxine hydrochloride in $0.1 \mathrm{~N} \mathrm{HCl}$

\subsection{DRUG - EXCIPIENT COMPATIBILITY STUDIES:}

FOURIER TRANSFORM-INFRRED SPECTROSCOPY:

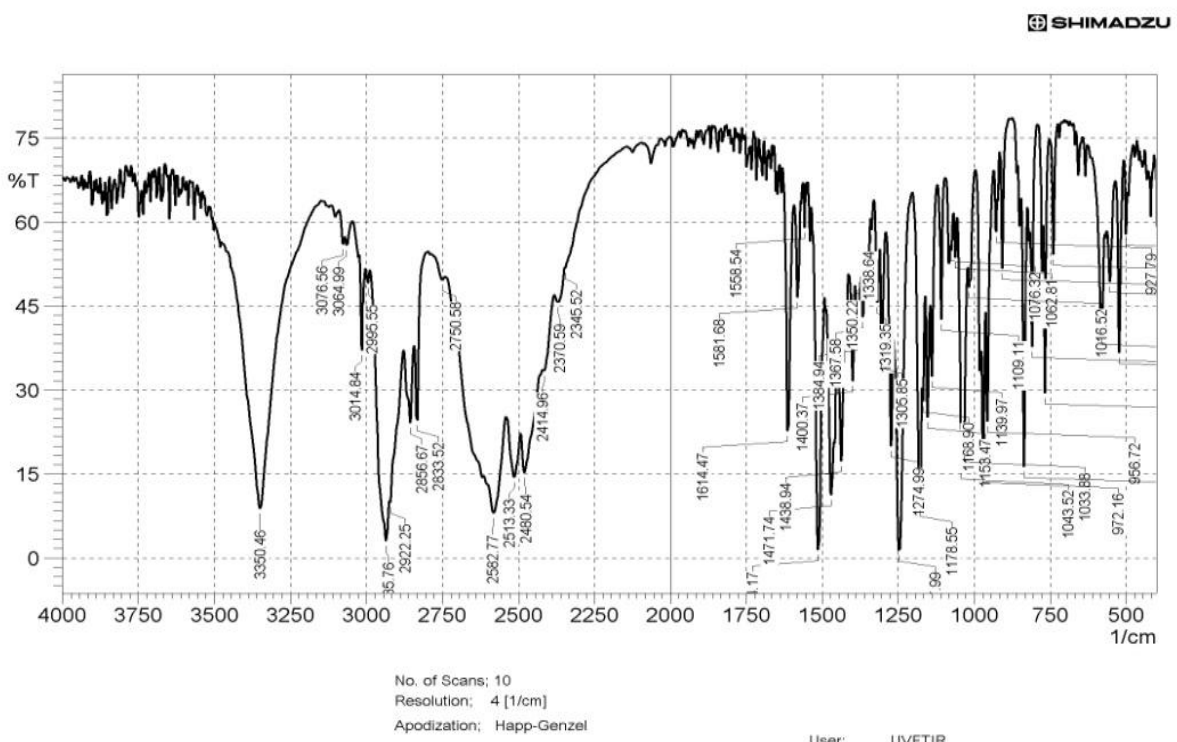

Fig : FT-TR Spectrum of Venlaflaxine Hydrochloride pure drug.

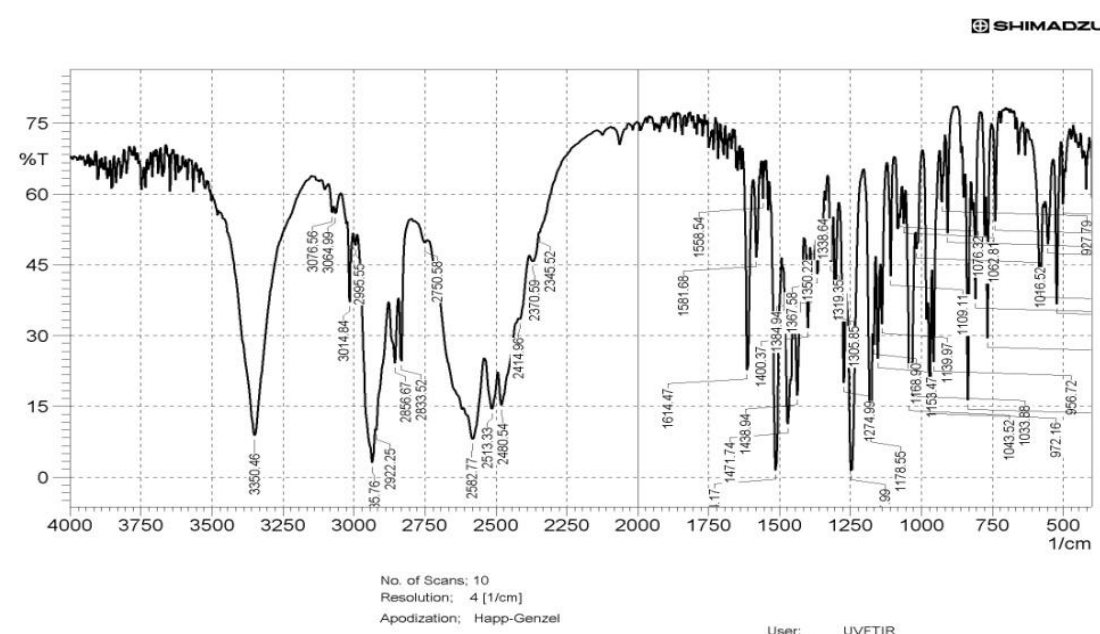

Fig: FT-IR Spectrum of Optimised Formulation 


\subsection{OPTIMIZATION OF SODIUM BICARBONATE CONCENTRATION :}

Three formulations were prepared with varying concentrations of sodium bicarbonate. The formulation containing sodium bicarbonate in 50mg concentration showed less floating lag time of 4 min and the tablet was in floating condition for more than 12 hours.

\subsection{IN-VITRO DRUG RELEASE STUDIES:}

TABLE: Dissolution Data of Venlaflaxine Hydrochloride Tablets Prepared With Guar gum In Different Concentrations

\begin{tabular}{|c|c|c|c|c|}
\hline \multirow{2}{*}{$\begin{array}{l}\text { TIME } \\
\text { (hr) }\end{array}$} & \multicolumn{4}{|c|}{ CUMULATIVE PERCENT DRUG DISSOLVED } \\
\hline & F1 & F2 & F3 & F4 \\
\hline 0.5 & 21.73 & 18.52 & 15.36 & $\mathbf{1 3 . 5 3}$ \\
\hline 1 & 59.23 & 37.47 & 25.93 & 25.97 \\
\hline 3 & 94.873 & 65.85 & 49.65 & 40.7 \\
\hline 4 & 94.873 & 77.54 & 56.34 & 49.38 \\
\hline 7 & & & 86.49 & 72.52 \\
\hline 8 & & & 91.65 & $\mathbf{7 7 . 8 8}$ \\
\hline 9 & & & 99.45 & 86.6 \\
\hline 10 & & & & 89.09 \\
\hline 11 & & & & 94.52 \\
\hline
\end{tabular}

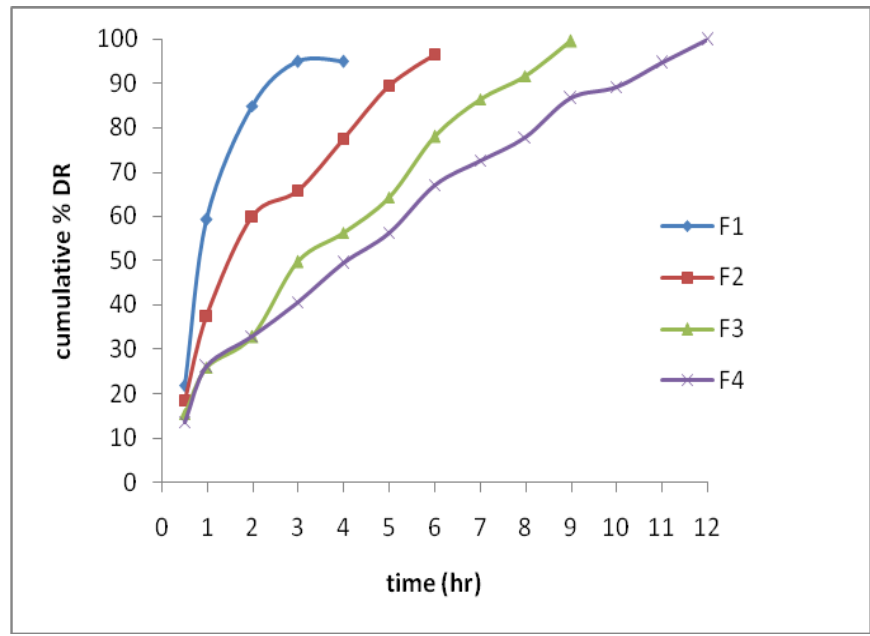

Fig: Dissolution profile of VENLAFLAXINE HCl floating tablets (F1, F2, F3, F4 formulations).

TABLE: Dissolution Data of Venlaflaxine Hydrochloride Tablets Prepared With HPMCK15M In Different Concentrations

\begin{tabular}{|c|c|c|c|c|}
\hline \multirow{2}{*}{$\begin{array}{ll} & \text { TIME } \\
\text { (hr) } & \end{array}$} & \multicolumn{4}{|c|}{ CUMULATIVE PERCENT DRUG DISSOLVED } \\
\hline & F5 & F6 & F7 & F8 \\
\hline 0.5 & 25.45 & 23.42 & 21.43 & 19.62 \\
\hline 1 & 36.26 & 39.73 & 34.35 & 27.86 \\
\hline 2 & 52.16 & 47.63 & 43.27 & 36.35 \\
\hline 3 & 70.01 & 54.04 & $\mathbf{5 0 . 3 5}$ & 41.45 \\
\hline 4 & 87.26 & 62.25 & 58.92 & 47.80 \\
\hline 5 & 93.10 & 71.33 & 66.45 & 55.25 \\
\hline 6 & & 87.41 & 72.47 & 60.24 \\
\hline 7 & & 96.84 & 80.47 & 66.73 \\
\hline 8 & & & 89.32 & 71.34 \\
\hline 9 & & & 98.54 & 78.52 \\
\hline 10 & & & & 80.17 \\
\hline 11 & & & & 88.75 \\
\hline 12 & & & & 96.33 \\
\hline
\end{tabular}




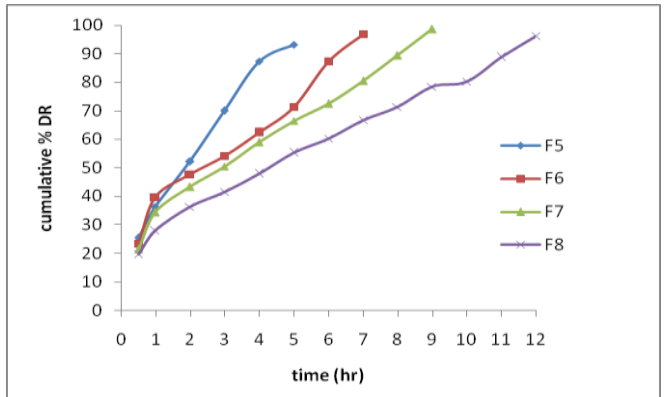

Fig: Dissolution profile of Venlaflaxine $\mathrm{HCl}$ floating tablets (F5, F6, F7, F8 formulations).

TABLE: Dissolution Data of Venlaflaxine Hydrochloride Tablets Prepared With HPMC K100M In Different Concentrations

\begin{tabular}{|c|c|c|c|c|}
\hline \multirow{2}{*}{$\begin{array}{l}\text { TIME } \\
\text { (hr) }\end{array}$} & \multicolumn{4}{|c|}{ CUMULATIVE PERCENT DRUG DISSOLVED } \\
\hline & F9 & F10 & F11 & F12 \\
\hline 0.5 & 19.81 & 16.89 & 13.28 & 11.21 \\
\hline 1 & 24.02 & 22.04 & 18.34 & 14.87 \\
\hline 2 & 30.70 & 29.43 & 25.49 & 19.19 \\
\hline 3 & 38.32 & 34.65 & 30.81 & 25.66 \\
\hline 4 & 45.25 & 40.18 & 35.19 & 29.32 \\
\hline 5 & 53.28 & 44.81 & 41.29 & 35.06 \\
\hline 6 & 61.92 & 49.89 & 47.01 & 40.13 \\
\hline 7 & 68.08 & 56.53 & 54.93 & 47.63 \\
\hline 8 & 75.44 & 61.43 & 59.73 & 53.71 \\
\hline 9 & 79.22 & 68.83 & 64.38 & 59.34 \\
\hline 10 & 84.90 & 72.98 & 70.75 & 63.27 \\
\hline 11 & 88.83 & 80.52 & 74.83 & 69.86 \\
\hline 12 & 95.90 & 86.65 & 80.53 & 74.97 \\
\hline
\end{tabular}

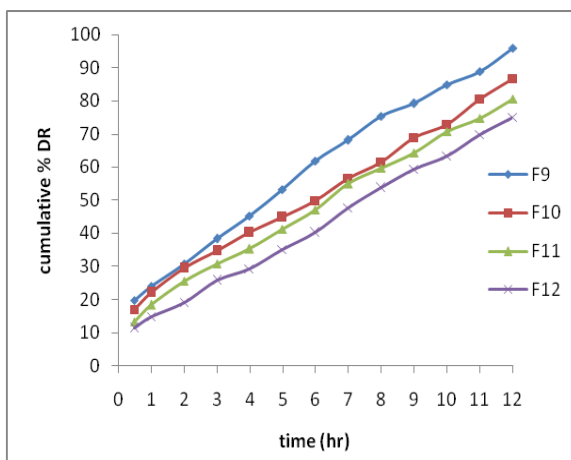

Fig: Dissolution profile of Venlaflaxine $\mathrm{HCl}$ floating tablets ( F9, F10, F11, F12 formulations)

\subsection{APPLICATION OF RELEASE RATE KINETICS TO DISSOLUTION DATA}

TABLE: Release kinetics data for optimised formulation

\begin{tabular}{|c|c|c|c|c|c|c|c|c|}
\hline $\begin{array}{l}\text { CUMULATIVE } \\
(\%) \text { RELEASE } \\
Q\end{array}$ & $\begin{array}{l}\text { TIM } \\
\text { E (T) }\end{array}$ & $\begin{array}{l}\text { ROOT } \\
\text { (T) }\end{array}$ & $\begin{array}{l}\text { LOG (\%) } \\
\text { RELEASE }\end{array}$ & $\begin{array}{l}\text { LOG } \\
(\mathbf{T})\end{array}$ & $\begin{array}{l}\text { LOG (\%) } \\
\text { REMAIN }\end{array}$ & $\begin{array}{l}\text { RELEASE RATE } \\
\text { (CUMULATIVE \% } \\
\text { RELEASE / t) }\end{array}$ & $\begin{array}{l}\text { 1/CUM\% } \\
\text { RELEASE }\end{array}$ & $\begin{array}{l}\text { PEPPAS } \\
\log Q / 100\end{array}$ \\
\hline $\mathbf{0}$ & $\mathbf{0}$ & 0 & & & 2.000 & & & \\
\hline 13.53 & 0.5 & 0.707 & 1.131 & -0.301 & 1.937 & 27.060 & 0.0739 & -0.869 \\
\hline 25.97 & 1 & 1.000 & 1.414 & 0.000 & 1.869 & 25.970 & 0.0385 & -0.586 \\
\hline 32.89 & 2 & 1.414 & 1.517 & 0.301 & 1.827 & 16.445 & 0.0304 & -0.483 \\
\hline 40.7 & 3 & 1.732 & 1.610 & 0.477 & 1.773 & 13.567 & 0.0246 & -0.390 \\
\hline 49.38 & 4 & 2.000 & 1.694 & 0.602 & 1.704 & 12.345 & 0.0203 & -0.306 \\
\hline 56.2 & 5 & 2.236 & 1.750 & 0.699 & 1.641 & 11.240 & 0.0178 & -0.250 \\
\hline 67.06 & 6 & 2.449 & 1.826 & 0.778 & 1.518 & 11.177 & 0.0149 & -0.174 \\
\hline 72.52 & 7 & 2.646 & 1.860 & 0.845 & 1.439 & 10.360 & 0.0138 & -0.140 \\
\hline 77.88 & 8 & 2.828 & 1.891 & 0.903 & 1.345 & 9.735 & 0.0128 & -0.109 \\
\hline 86.6 & 9 & 3.000 & 1.938 & 0.954 & 1.127 & 9.622 & 0.0115 & -0.062 \\
\hline 89.09 & 10 & 3.162 & 1.950 & 1.000 & 1.038 & 8.909 & 0.0112 & -0.050 \\
\hline 94.52 & 11 & 3.317 & 1.976 & 1.041 & 0.739 & 8.593 & 0.0106 & -0.024 \\
\hline 99.76 & 12 & 3.464 & 1.999 & 1.079 & -0.620 & 8.313 & 0.0100 & -0.001 \\
\hline
\end{tabular}




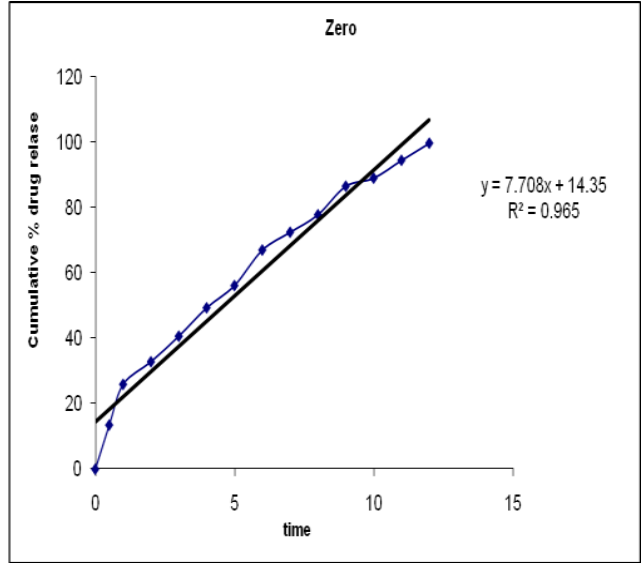

Fig : Zero order release kinetics graph

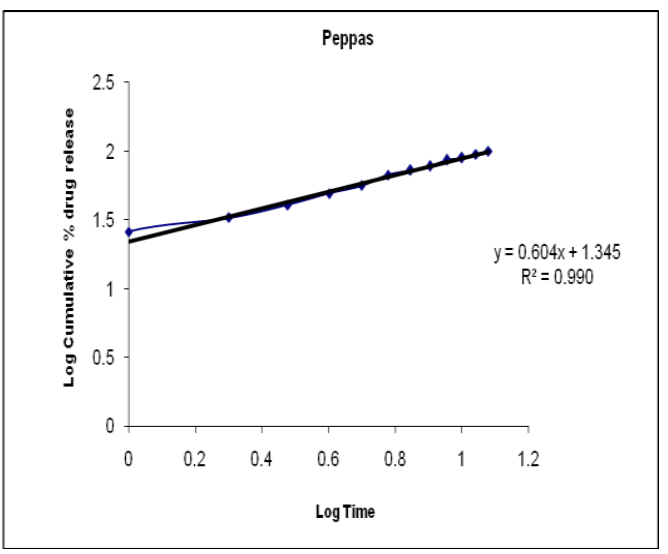

Fig: Kors meyer peppas graph

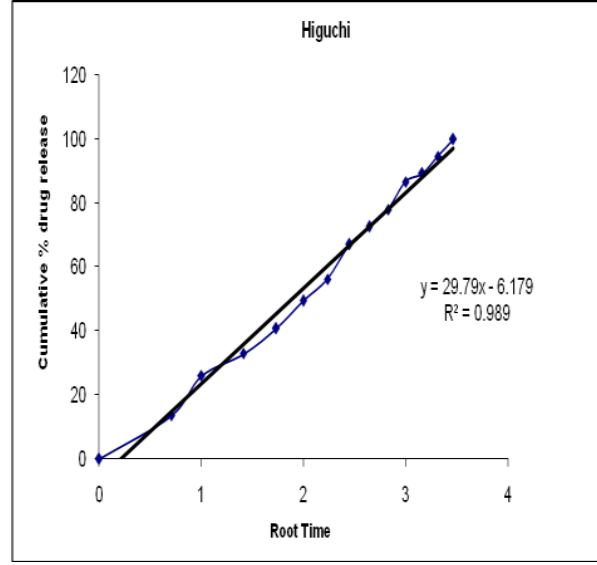

Fig : Higuchi release kinetics graph

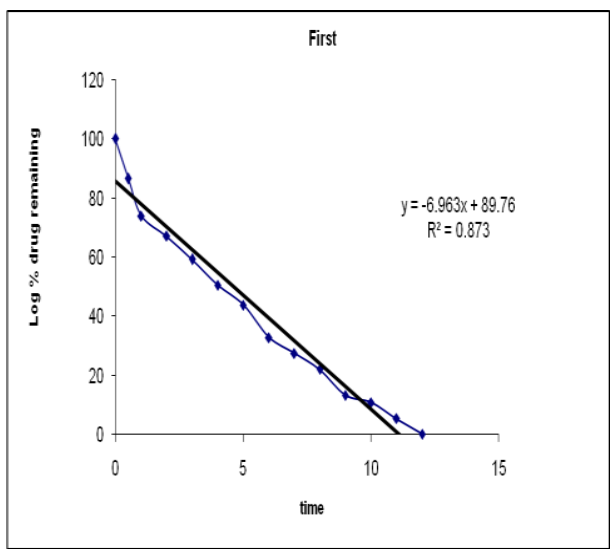

Fig: First order release kinetics graph

From the above graphs it was evident that the formulation F4 was followed non fickian peppas release kinetics.

\section{Conclusion}

In the present research work the gastro retentive floating matrix formulation of Venlaflaxine hydrochloride by using various hydrophilic polymers. Initially analytical method development was done for the drug molecule. Absorption maxima was determined based on that calibration curve was developed by using different concentrations. Gas generating agent sodium bicarbonate concentration was optimized. Then the formulation was developed by using different concentrations of polymers of various grades of HPMC and Guar gum. The formulation blend was subjected to various preformualation studies, flow properties and all the formulations were found to be good indicating that the powder blend has good flow properties. Among all the formulations the formulations prepared by using Guar gum were in the concentration of 120mg (F4) showed maximum drug release $99.76 \%$ in 12 hours with good floating lag time and duration of floating. The formulations prepared with HPMC K 15 M retarded the drug release up to 12 hours in the concentration of 120 $\mathrm{mg}$ (F8). The formulations prepared with HPMC K100M were also retarded the drug release for more than 12 hours. Hence they were not considered. The optimized formulation dissolution data was subjected to release kinetics, from the release kinetics data it was evident that the formulation followed peppas mechanism of drug release.

\section{Bibliography}

[1]. Leon Lachman, Herbert A. Liberman, the Theory and Practice of Industrial Pharmacy: P.293-302.

[2]. Robinson Jr, Lee V.H.L, Controlled drug delivery: Fundamentals and Applications, 2nd edn. Marcel Dekker, New york: (1978) P.2436.

[3]. Brahmankar D.M, Jaiswal S.B, Biopharmaceutics and Pharmacokinetics a treatise, 1st ed. Vallabh prakashan; New Delhi: (1995) P.64-70.

[4]. Chein Y.W, Novel Drug Delivery Systems, 2nd ed.: Marcel Dekker; New York: (1992) P.4-56.

[5]. Ansel, Pharmaceutical Dosage form and Drug Delivery System, Lipincott, 7th edition: P. 553.

[6]. Gennaro R.A. Remington,The Science and Practice of Pharmacy., 20th ed. New york : Lippincott Williams: (2000) P.1045.

[7]. Banker G.S, Rhodes C.T, Modern Pharmaceutics. 3rd ed. Marcel Dekker, New York: (1996) P.678-721.

DOI: $10.9790 / 3008-1203020111 \quad$ www.iosrjournals.org $\quad 10 \mid$ Page


[8]. Vyas S.P, Khar R.K, Controlled Drug Delivery: Concepts and Advances, 1st ed. Vallabh prakashan, New Delhi: (2002) P.345-376.

[9]. P.G.Yeole, Floating Drug Delivery System: Need and Development, Ind. J. Pharm Sci., (2005): 67(3); $265-272$.

[10]. Shweta Arora, Floating Drug Delivery: A Review, AAPS Pharmscitech. (2005): 47(11); P.268-272.

[11]. Libo Yang, A New Intragastric Delivery System for the Treatment of H.Pylori associated with gastric ulcers, Elsevier J. of controlled release., Apr(1999): 34 (5); P. 215-222.

[12]. Ross and Wilson, Anatomy Physiology and Health Education. 9th ed. Churchil Livingston, P. 295-311.

[13]. Wilson K.R.W, Waugh A. Anatomy and physiology in Health and Illness, 9th ed. Churchill Livingstone: London: (1996). P. 342-345.

[14]. Garima Chawla, Gupta, Pharmaceutical technology, July (2003): 23(9); P.39-48.

[15]. Desai S, Bolton S. A Floating Controlled Release System: In-vitro and In-vivo evaluation, J. Pharm. Res., (1993): 10; P.1321-1325.

[16]. Garg S, Sharma S. Gastroretentive Drug Delivery Systems, Pharmatech, (2003): P.160-164.

[17]. Dr.Jose, Khalid Shah, Gastroretentive Drug Delivery System, Business brief, Pharmtech., (2003) P. $165-173$.

[18]. Deshpande A.A, Shah N.H, Rhodes C.T, Development of a Novel Controlled Release System for Gastric Retention, J. Pharm. Res., (1997): 14(6); P. 815-819.

[19]. Garima Chawla- A means to address regional variability in intestinal drug absorption: Pharmtech. (2003) P.234-238.

[20]. David S.S. The effect of density on the gastric emptying on single and multiple unit dosage forms. J. Pharm Res., (1986): 3; P.208213.

[21]. H.G. Sivakumar, Floating Drug Delivery System for Prolonged Gastric Residence time: A review, Ind. J. Pharm. Edu., oct-dec-2004 P.311-316.

[22]. B.N.Singh, H.Kim, Floating drug delivery system an approach to control drug delivery via gastric retention, J. Controlled Release., (2000): 63(7); P. 235-259.

[23]. B.Y.Choi, H.J.Park, Preparation of alginate beads for floating drug delivery system: effect of co2 gas forming agent. J. Contolled Release., (2000): 25(6); P.488-491.

[24]. Timmermans J, Moes A.J. The cut off size for gastric emptying of dosage forms, J. Pharm. Sci., (1993): (82); P. 854.

[25]. Bhavana V, Khopade A.J, Jain W.D, Shelly and Jain N.K, Targeted Oral Drug Delivery, Indian drugs., (1996): (33); P. $365-373$. 